\title{
Safety of $0.5 \%$ hydrogen peroxide mist used in the disinfection gateway for COVID-19
}

\author{
Parayanthala Valappil Mohanan ${ }^{1}$ (D) $\cdot$ Vijayan Sangeetha $^{1} \cdot$ Arumugham Sabareeswaran $^{2} \cdot$ \\ Vayalappil Muraleedharan ${ }^{3} \cdot$ Krishnan Jithin $^{4} \cdot$ Unnikrishnan Vandana ${ }^{1} \cdot$ Sheela Bhasi Varsha ${ }^{1}$
}

Received: 19 April 2021 / Accepted: 23 June 2021 / Published online: 7 July 2021

(C) The Author(s), under exclusive licence to Springer-Verlag GmbH Germany, part of Springer Nature 2021

\begin{abstract}
Hydrogen peroxide $\left(\mathrm{H}_{2} \mathrm{O}_{2}\right)$ is a reactive chemical used in a wide range of applications. Most importantly, it is used for sterilization process in health care environment. In the present study, safety assessment of $0.5 \%$ of $\mathrm{H}_{2} \mathrm{O}_{2}$ and its mist intended to be used in the disinfection gateway for COVID-19 was evaluated. Skin irritation and repeated-dose inhalation toxicity studies were carried out in rabbits and rats, respectively. In Skin irritation study, New Zealand white rabbits were exposed topically with $0.5 \%$ $\mathrm{H}_{2} \mathrm{O}_{2}$ solution and observed for $24 \mathrm{~h}, 48 \mathrm{~h}$, and $72 \mathrm{~h}$. For repeated-dose inhalation toxicity study, Wistar rats (both male and female) were exposed (whole body exposure) to $0.5 \%$ of $\mathrm{H}_{2} \mathrm{O}_{2}$ mist, at a concentration of 11.022 (low dose-2-min exposure), 22.044 (medium dose - 4-min exposure), and $55.11 \mathrm{mg} / \mathrm{kg}$ (high dose/high dose recovery - 10-min exposure) body weight, daily for 7 days. Rats in the high-dose recovery group $(55.11 \mathrm{mg} / \mathrm{kg}$ - 10-min exposure) were kept for another 7 days without any exposure. A toxicological evaluation was done based on general health parameters, hematology, serum biochemistry, gross necropsy, and histopathological data. The results of the study indicated that there was no skin irritation potential induced on exposure of $0.5 \%$ of $\mathrm{H}_{2} \mathrm{O}_{2}$ to rabbits. Similarly, the inhalation toxicity of $0.5 \%$ of $\mathrm{H}_{2} \mathrm{O}_{2}$ mist imparts no evidence of hematological, biochemical, gross pathology, or histopathological abnormalities in rats. Further, at the laboratory condition stimulated, the NOEL was found to be $55.11 \mathrm{mg} / \mathrm{kg}$ body weight. Hence, the present study concluded that $0.5 \% \mathrm{H}_{2} \mathrm{O}_{2}$ or its mist used in the disinfection gateway for COVID-19 failed to induce any skin irritation in rabbits or inhalation toxicity in rats.
\end{abstract}

Keywords Hydrogen peroxide $\cdot$ Disinfectant $\cdot$ Skin irritation $\cdot$ Inhalation toxicity $\cdot$ NOEL $\cdot$ COVID-19

\section{Introduction}

Responsible Editor: Lotfi Aleya

Parayanthala Valappil Mohanan

mohanpv10@gmail.com; mohanpv@sctimst.ac.in

1 Division of Toxicology, Sree Chitra Tirunal Institute for Medical Sciences and Technology (Govt. of India), Biomedical Technology Wing, Poojapura, Trivandrum, Kerala 695 012, India

2 Division of Histopathology, Sree Chitra Tirunal Institute for Medical Sciences and Technology (Govt. of India), Biomedical Technology Wing, Poojapura, Trivandrum, Kerala 695 012, India

3 Division of Artificial Internal Organs, Sree Chitra Tirunal Institute for Medical Sciences and Technology (Govt. of India), Biomedical Technology Wing, Poojapura, Trivandrum, Kerala 695 012, India

4 Divison of Medical Instrumentation, Sree Chitra Tirunal Institute for Medical Sciences and Technology (Govt. of India), Biomedical Technology Wing, Poojapura, Trivandrum, Kerala 695 012, India
Hydrogen peroxide is a colourless liquid easily decompose to oxygen and water in the presence of most metals and alkaline solutions. It was first synthesized by Louis Jacques Thénard in 1818 by reaction of nitric acid with barium peroxide. Hydrogen peroxide $\left(\mathrm{H}_{2} \mathrm{O}_{2}\right)$ was generally used and available in concentrations ranging from 3 to $90 \% . \mathrm{H}_{2} \mathrm{O}_{2}$, an oxidizing agent, is actively used in wide range of applications, mainly in medicinal and household purposes (3-30\%). Industries mostly use concentrated hydrogen peroxide (30-70\%) for the purpose of bleaching (Ernstgard et al. 2012). Aqueous solutions of hydrogen peroxide in the range of 3-6\% in water demonstrate broad spectrum antimicrobial activity depending on the concentration and exposure time; hence, it is also included in cosmetics, toothpaste, and detergents (McDonnell 2009). $\mathrm{H}_{2} \mathrm{O}_{2}$ both in liquid and gaseous form is widely used for biocidal applications(Linley et al. 2012). In health care facilities, vaporized hydrogen peroxide is used in sterilization of 
medical devices (Rutala and Weber 2015) and hydrogen peroxide-based automated room disinfection systems are utilized in pharmaceutical environments (Murdoch et al. 2016). Recently, vaporized hydrogen peroxide (VHP) as a rapid sterilization technology is used as broad spectrum antimicrobial with virucidal, bactericidal, fungicidal, and sporicidal activity (Lerouge and Simmons 2012). Virucidal effect of hydrogen peroxide vapor disinfection against poliovirus, rotavirus, adenovirus, MNV1, and influenza A virus has been documented (Tuladhar et al. 2012). Concern was raised on the toxic effect of hydrogen peroxide due to its wide spread application. It has been documented that hydrogen peroxide once entered the blood circulation; it is rapidly decomposed in blood and remains unavailable systemically. Hydrogen peroxide induces toxicity depending on the route and concentration of exposure. The permissible exposure limit as per Occupational Safety and Health Administration (OSHA) is found to be $1 \mathrm{ppm}$ (averaged over an 8-h work shift) (ATSDR, 2002). The 8-h limit value of hydrogen peroxide was decreased from 1 down to $0.05 \mathrm{ppm}$ by MAK commission. Among the routes of exposure (ingestion, inhalation, and dermal contact), inhalation is considered to be the major route for gaseous form exposure resulting in toxicity.

Studies on human have reported industrial workers exposed to hydrogen peroxide 1.2 to $2.4 \mathrm{~mL} / \mathrm{m}^{3}$ with peak exposures of $8 \mathrm{~mL} / \mathrm{m}^{3}$ caused irritation of the eyes and throat, nasal congestion, coughing, and asthma symptoms revealing severe signs of inhalation toxicity (Hartwig and Arand 2019). Animal studies have reported dermal $\mathrm{LD}_{50}$ of $90 \%$ hydrogen peroxide solution, between 700 and $5000 \mathrm{mg} / \mathrm{kg}$ body weight in various species; among them, the rat was the least sensitive (EC, 2003). Earlier studies also reported that workers exposed to $\mathrm{H}_{2} \mathrm{O}_{2}$ concentrations, less than $1 \mathrm{ppm}$, showed rough skin on the hands and decolorized hairs (Suenaka et al. 1984). Studies on rodents documented that the oral $\mathrm{LD}_{50}$ of hydrogen peroxide (30-70\%) is found to be $694-1270 \mathrm{mg} / \mathrm{kg}$ body weight in rats (EC, 2003). In a 28-day study, Wistar rats exposed to hydrogen peroxide vapor in concentrations of 0,2 , 10 , or $25 \mathrm{~mL} / \mathrm{m}^{3}$ for $6 \mathrm{~h}$ per day and 5 days per week (noseonly exposure) showed concentration-depended lung toxicity (CEFIC 2002). Studies also documented hydrogen peroxide as a well-known irritant to the mucous membranes and the airways (Watt et al. 2004). Even though numerous studies on hydrogen peroxide are available in literature, consistent and accurate toxicity studies remain elusive. Recently, exploiting virucidal, bactericidal, and disinfectant activity of $0.5 \%$ of $\mathrm{H}_{2} \mathrm{O}_{2}$ mist, a disinfectant gate way was developed intended to be used for COVID-19 to control the extent of exposure to the viral load (Krishnan et al. 2020). In the present study, safety assessment of $0.5 \% \mathrm{H}_{2} \mathrm{O}_{2}$ mist used in the disinfection gateway for COVID-19 was evaluated for skin irritation and repeated-dose inhalation toxicity studies in New Zealand white rabbits and Wistar rats.

\section{Materials and methods}

\section{Animals}

Wistar rats, both male and female of 8 weeks old with body weight range 170-250 g, were selected for inhalation toxicity study, and New Zealand white rabbit weighing $2.0-2.6 \mathrm{~kg}$ was chosen for skin irritation test. The animals were selected from an inbred colony maintained under the controlled conditions of $22 \pm 3^{\circ} \mathrm{C}$, humidity of $30-70 \%$, and 12-h photoperiod with sterile food and water. Experiments were performed after obtaining approval by the Institutional Animal Ethics Committee. The animal care and handling were according to the Committee for the Purpose of Control and Supervision of Experiments on Animals (CPCSEA) guidelines for animal experimentation (Institutional Animal Ethics Committee approval no.: SCT/IAEC-320/FEBRUARY/2019/101 (skin irritation) and SCT/IAEC-345/May/2020/105 (inhalational toxicity)).

\section{Skin irritation}

Skin irritation potential was carried out as per international organization for standardization (ISO 10993-10 2010). Three New Zealand white rabbits were used for the study. $0.5 \%$ $\mathrm{H}_{2} \mathrm{O}_{2}$ solution $\left(3 \% \mathrm{H}_{2} \mathrm{O}_{2}\right.$ IP-Pharmacy grade) and physiological saline (control) were exposed topically on the upper left and right hand side of the clipped skin of 3 rabbits $(0.5 \mathrm{~mL} /$ site). Application sites were covered with occlusive bandage for $4 \mathrm{~h}$. The test sample and control application sites were observed at $1 \mathrm{~h}, 24 \mathrm{~h}, 48 \mathrm{~h}$, and $72 \mathrm{~h}$ after removal of patches and observed for any tissue reactions. Skin irritation responses of rabbits were scored and recorded as ISO 10993-10.

\section{Repeated-dose inhalation toxicity}

Repeated-dose inhalation toxicity study was performed based on OECD guidelines 412 (OECD 2018). Wistar rats of either sex (20 male and 20 female) were randomly assigned to five different groups: low-dose, medium-dose, high-dose, highdose recovery, and control groups respectively $(n=4)$. Wistar rats (both male and female) were exposed (whole body exposure) to $0.5 \%$ of $\mathrm{H}_{2} \mathrm{O}_{2}$ mist (2-10 micron diameter), at a concentration of 11.022 (low dose-2-min exposure), 22.044 (medium dose-4-min exposure), and $55.11 \mathrm{mg} / \mathrm{kg}$ body weight (high dose/high dose recovery-10-min exposure), daily for 7 days. Rats in the high-dose recovery group $(55.11 \mathrm{mg} / \mathrm{kg}$ - 10 -min exposure) were kept for another 7 days without any exposure. Control animals received only normal environmental conditions or exposure. All animals in each group (control, low, medium, and high) were sacrificed after 7 days. Recovery group animals were kept further 7 more days and sacrificed on the $14^{\text {th }}$ day. The justification for selection of 
dose/exposure is based on the multiple dose of human exposure (dose human exposure X6, X12, and X30 times) as shown in Table 1. All animals were subjected to daily observations for mortality and behavioral changes. Body weight of the animals before and after exposure was also recorded.

\section{Body weight}

In the repeated-dose inhalation toxicity study, the body weight of Wistar rats exposed to hydrogen peroxide mist $(0.5 \%)$ and control animals were recorded before and after completion of exposure.

\section{Hematology}

Wistar rats were anesthetized (diethyl ether), and blood was collected from retro-orbital venous plexus in sample tubes containing ethylene diamine tetra acetic acid (EDTA) and examined for the following parameters: white blood cell counts (WBC), red blood cell counts (RBC), hemoglobin concentration $(\mathrm{Hb})$, hematocrit $(\mathrm{HCT}), \mathrm{MCV}$, mean corpuscular volume (MCHC), and platelets (PLT) using a hematology analyzer (Abc VET, New Delhi).

\section{Serum biochemistry}

Blood samples were collected from retro-orbital venous plexus of rats and allowed to clot. The serum samples of both $0.5 \%$ of $\mathrm{H}_{2} \mathrm{O}_{2}$ mist-exposed and non-exposed were separated after centrifugation at $3000 \mathrm{rpm}$ for $5 \mathrm{~min}$. The serum was subjected to use for the estimation of alanine amino transferase (ALT), aspartate amino transferase (AST), alkaline phosphatase (ALP), triglycerides, albumin, total protein, total bilirubin, creatinine, glucose, cholesterol, and urea using an automated biochemical analyzer (ERBA XL 300, Germany) and as per the manufacturer's instructions.

\section{Gross necropsy}

At the end of observation period, all the animals in control and test groups were sacrificed by cervical dislocation. All the animals were subjected to gross pathological evaluations. Organs, such as the lungs, cerebrum, cerebellum, liver, spleen, pancreas, kidneys, heart, thymus, adrenal, testes, epididymis, ovaries, uterus, cervix, nasal cavity, pharynx, larynx, and trachea, were subjected to gross pathological evaluations.

\section{Histopathology}

All the animals were scarified at the end of the experimental period. The following organs from the control and test groups were subjected to histopathological evaluations. The organs are the lungs, cerebrum, cerebellum, liver, spleen, pancreas, kidneys, heart, thymus, adrenal, testes, epididymis, ovaries, uterus, cervix, nasal cavity, pharynx, larynx, and trachea. All the above organs were collected and preserved in $10 \%$ buffered formalin. Blocks of tissue were processed in automatic tissue processor and embedded in molten paraffin. Fivemicrometer $(3-5-\mu \mathrm{m})$-thick sections were cut from the block and stained with hematoxylin and eosin and subjected to microscopical examinations.

\section{Antioxidant assay}

\section{Preparation tissue homogenate}

Liver homogenate was prepared as follows: liver tissues of Wistar rats exposed to $0.5 \%$ of $\mathrm{H}_{2} \mathrm{O}_{2}$ mist at varying doses and control animals were dissected and washed with saline $(0.9 \%)$ to remove excess blood. The tissues were homogenized in $0.1 \mathrm{M}$ phosphate buffer using a tissue homogenizer (Polytron P3100) at $1000 \mathrm{rpm}$ and subsequently centrifuged to pellet cell debris. The supernatant was collected and stored at $-80{ }^{\circ} \mathrm{C}$ until used for antioxidant assays.

\section{Total protein assessment}

Total protein concentration of liver homogenate was determined (Lowry et al. 1951) with bovine serum albumin as standard in a UV/Vis spectrophotometer (Perkin Elmer, USA) at $690 \mathrm{~nm}$.
Table 1 Experimental design: repeated-dose inhalation toxicity of $0.5 \% \mathrm{H}_{2} \mathrm{O}_{2}$ mist

\begin{tabular}{llllll}
\hline No. & Group & \multicolumn{2}{l}{ No. of animals (rats) } & Duration of exposure & $\begin{array}{l}\text { Dose mg/kg body weight } \\
\text { of } \mathrm{H}_{2} \mathrm{O}_{2} \text { mist }\end{array}$ \\
\cline { 3 - 4 } & \multicolumn{2}{c}{ Male } & Female & & \\
\hline 1 & Control & 4 & 4 & $0 \mathrm{~min}$ & 0 \\
2 & Low dose & 4 & 4 & $2 \mathrm{~min}$ & $11.022 \mathrm{mg} / \mathrm{kg}$ \\
3 & Medium dose & 4 & 4 & $4 \mathrm{~min}$ & $22.044 \mathrm{mg} / \mathrm{kg}$ \\
4 & High dose & 4 & 4 & $10 \mathrm{~min}$ & $55.11 \mathrm{mg} / \mathrm{kg}$ \\
5 & High dose recovery & 4 & 4 & $10 \mathrm{~min}$ & $55.11 \mathrm{mg} / \mathrm{kg}$ \\
\hline
\end{tabular}




\section{Reduced glutathione level}

The amount of reduced glutathione (GSH) in the liver homogenate of Wistar rats exposed to $0.5 \% \mathrm{H}_{2} \mathrm{O}_{2}$ mist was determined with slight modifications of the method of Moron, Depierre, and Mannervik (Moron et al. 1979). The thiol reagent DTNB (5, 5'-dithiobis-2-nitrobenzoic acid) reacts with GSH to form a chromophore, 5-thionitrobenzoic acid (TNB), and it is measured using UV/Vis spectrophotometer (Perkin Elmer, USA) at $412 \mathrm{~nm}$.

\section{Glutathione peroxidase}

GPx activity in liver tissue homogenate of Wistar rats exposed to $0.5 \% \mathrm{H}_{2} \mathrm{O}_{2}$ mist was analyzed (Rotruck et al. 1973). Glutathione peroxidase (GPx) results in the formation of glutathione disulfide (GSSG). GSH remained after enzyme catalyzed reaction complexes with DTNB, which absorbs at maximum wavelength of $412 \mathrm{~nm}$. Enzyme activity was expressed as $\mathrm{mg}$ of GSH consumed/min/mg protein.

\section{Statistical analysis}

Data were expressed as mean \pm SD. Statistical comparisons between control exposed groups were done using one-way ANOVA followed by Tukey's post hoc test (SPSS ver 22, IBM Corp.) and significant difference between initial and final body weight by paired $T$-test. The $p$ values $(p<0.01, p<0.05)$ are considered as significant.

\section{Result}

\section{Skin irritation test}

Skin irritation potential on exposure to $0.5 \% \mathrm{H}_{2} \mathrm{O}_{2}$ was determined and depicted in Table 2. Rabbits showed no signs of skin irritation after exposure to $0.5 \% \mathrm{H}_{2} \mathrm{O}_{2}$. The treated skin remained intact' no oedema and erythema compared to control site was observed. Enema and erythema score was categorized (ISO 10993-10) and recorded as "0" in each rabbit on removing the test material and at the end of observation period.

\section{Inhalation toxicity}

\section{Clinical signs and survival}

No mortality or morbidity was found in both control or tested groups throughout the experimental period. No clinical signs of toxicity were observed on exposure to $0.5 \%$ hydrogen peroxide mist in all study groups (low dose, medium dose, high dose, and high dose recovery).

\section{Body weight}

Gain in body weight was observed in all groups (low dose, medium dose, high dose, and high dose recovery) exposed to $0.5 \% \mathrm{H}_{2} \mathrm{O}_{2}$ mist. Significant increase in body weight was observed when compared to initial body weight (as shown in Table 3).

\section{Hematology}

Hematological parameters were analyzed separately for males and females. The results (Table 4) revealed that all the hematological parameters were comparable with the control group, both in males and females. The RBC count and percentage of HCT of control animal were found to be less than the normal range. It is suggested that the alternation observed in the $\mathrm{RBC}$ count or percentage of HCT is not related with the test sample exposure. There is a statistical significance observed in MCV and $\mathrm{MCHV}$ values, but the values are within the normal range.

\section{Serum biochemistry}

Biochemical analysis revealed serum ALT, bilirubin, creatinine, triglycerides, total protein, and albumin in both female and male Wistar rats exposed to $0.5 \% \mathrm{H}_{2} \mathrm{O}_{2}$ mist for a period of 7 days were comparable with that of control (Tables 5 and
Table 2 Skin irritation score of rabbits exposed to $0.5 \% \mathrm{H}_{2} \mathrm{O}_{2}$

\begin{tabular}{|c|c|c|c|c|c|c|c|}
\hline \multirow{2}{*}{$\frac{\text { Animal }}{1 q}$} & \multirow{2}{*}{$\begin{array}{l}\text { Group } \\
\text { Control }\end{array}$} & \multicolumn{2}{|c|}{ Irritation score $24 \mathrm{~h}$} & \multicolumn{2}{|c|}{ Irritation score $48 \mathrm{~h}$} & \multicolumn{2}{|c|}{ Irritation score $72 \mathrm{~h}$} \\
\hline & & Erythema & Oedema & Erythema & Oedema & Erythema & Oedema \\
\hline & Test & 0 & 0 & 0 & 0 & 0 & 0 \\
\hline \multirow[t]{2}{*}{$2 \hat{\jmath}$} & Control & 0 & 0 & 0 & 0 & 0 & 0 \\
\hline & Test & 0 & 0 & 0 & 0 & 0 & 0 \\
\hline \multirow[t]{2}{*}{$30^{\lambda}$} & Control & 0 & 0 & 0 & 0 & 0 & 0 \\
\hline & Test & 0 & 0 & 0 & 0 & 0 & 0 \\
\hline \multicolumn{2}{|c|}{ Primary irritation score } & 0 & & & & & \\
\hline \multicolumn{2}{|c|}{ Irritation index } & 0 & & & & & \\
\hline
\end{tabular}


Table 3 Body weight of Wistar rats before and after exposure to $0.5 \% \mathrm{H}_{2} \mathrm{O}_{2}$ mist

\begin{tabular}{|c|c|c|c|c|}
\hline Groups & $\begin{array}{l}\text { Initial body weight }(\mathrm{g}) \\
\text { Male }\end{array}$ & Final body weight (g) & $\begin{array}{l}\text { Initial body weight }(\mathrm{g}) \\
\text { Female }\end{array}$ & Final body weight (g) \\
\hline Control & $242.33 \pm 9.54$ & $280.92 \pm 11.41 * *$ & $179.71 \pm 6.18$ & $195.72 \pm 2.93^{*}$ \\
\hline Low dose & $171.50 \pm 13.82$ & $263.02 \pm 7.76^{* *}$ & $171.82 \pm 11.50$ & $199.80 \pm 7.74^{*}$ \\
\hline Medium dose & $233.11 \pm 10.99$ & $262.15 \pm 18.14 * *$ & $183.55 \pm 9.33$ & $192.26 \pm 5.65$ \\
\hline High dose & $217.28 \pm 33.86$ & $252.53 \pm 45.53 * *$ & $183.96 \pm 9.28$ & $190.31 \pm 11.94$ \\
\hline High recovery ${ }^{\$}$ dose & $195.50 \pm 18.53$ & $285.00 \pm 26.52 * *$ & $176.70 \pm 5.80$ & $200.80 \pm 10.17 * *$ \\
\hline
\end{tabular}

Data are expressed as mean $\pm \mathrm{SD}$. Statistical significance was determined using paired $T$-test. $* * p<0.01 ; * p<0.05$ compared to initial body weight (final body weight after 7 days of exposure); ${ }^{\$}$ final bodyweight after14 days

Table 4 Hematological values of rats exposed to $0.5 \% \mathrm{H}_{2} \mathrm{O}_{2}$ mist

\begin{tabular}{llllllll}
\hline Groups & $\mathrm{Hb}(\mathrm{g} / \mathrm{dL})$ & $\mathrm{RBC}\left(\times 10^{6} / \mathrm{mm}^{3}\right)$ & $\mathrm{WBC}\left(\times 10^{3} / \mathrm{mm}^{3}\right)$ & $\mathrm{PLT}\left(\times 10^{3} / \mathrm{mm}^{3}\right)$ & $\mathrm{HCT}(\%)$ & $\left.\mathrm{MCV}(\mathrm{um})^{3}\right)$ & $\mathrm{MCHC}(\mathrm{g} / \mathrm{dL})$ \\
\hline Male & & & & & & & \\
Control & $15.07 \pm 0.58$ & $5.23 \pm 0.19$ & $10.00 \pm 2.80$ & $836.3 \pm 41.30$ & $34.20 \pm 1.12$ & $65.30 \pm 1.71$ & $44.13 \pm 0.61$ \\
Low dose & $15.10 \pm 0.49$ & $5.98 \pm 0.15^{*}$ & $8.40 \pm 2.30$ & $815.3 \pm 60.11$ & $37.10 \pm 1.36^{*}$ & $61.80 \pm 2.50^{*}$ & $40.60 \pm 0.24 * *$ \\
Medium dose & $15.63 \pm 0.79$ & $6.00 \pm 0.22^{*}$ & $8.15 \pm 1.90$ & $847.5 \pm 26.30$ & $37.53 \pm 1.94^{*}$ & $61.30 \pm 1.50^{* *}$ & $41.70 \pm 0.58^{* *}$ \\
High dose & $14.50 \pm 0.61$ & $4.85 \pm 0.12$ & $8.68 \pm 1.40$ & $848.5 \pm 22.65$ & $32.03 \pm 1.68$ & $66.00 \pm 1.63$ & $45.30 \pm 0.77$ \\
High dose recovery & $15.00 \pm 0.64$ & $6.20 \pm 0.19^{* * \#}$ & $10.50 \pm 4.48$ & $888.7 \pm 19.63$ & $38.90 \pm 2.97 * * \#$ & $59.80 \pm 1.50^{* * \#} 37.88 \pm 1.46^{* * \#}$ \\
Female & & & & & & \\
Control & $14.65 \pm 0.43$ & $4.85 \pm 0.05$ & $6.35 \pm 2.70$ & $824.5 \pm 66.54$ & $31.78 \pm 0.54$ & $65.30 \pm 0.50$ & $45.58 \pm 0.85$ \\
Low dose & $14.70 \pm 0.82$ & $5.13 \pm 0.17$ & $6.18 \pm 1.29$ & $776.3 \pm 50.26$ & $32.45 \pm 1.76$ & $63.30 \pm 2.06^{*}$ & $45.35 \pm 0.85$ \\
Medium dose & $14.18 \pm 0.45$ & $4.85 \pm 0.21$ & $6.02 \pm 0.58$ & $862.0 \pm 18.13$ & $31.23 \pm 1.41$ & $64.80 \pm 0.50$ & $45.33 \pm 0.84$ \\
High dose & $14.65 \pm 0.17$ & $5.68 \pm 0.22^{* *}$ & $6.03 \pm 0.59$ & $852.3 \pm 35.03$ & $33.93 \pm 1.38$ & $60.00 \pm 0.50^{* *}$ & $43.25 \pm 1.09 *$ \\
High dose recovery & $15.30 \pm 0.49$ & $6.74 \pm 0.44^{* * \#}$ & $6.53 \pm 0.55$ & $888.3 \pm 20.02$ & $39.20 \pm 2.18^{* * \#}$ & $58.00 \pm 0.82^{* * \#} 38.98 \pm 0.87 * * \#$
\end{tabular}

Data are expressed as mean $\pm \mathrm{SD}, n=4$. Statistical significance was determined using one-way ANOVA followed by Tukeys post hoc test. $* p<0.05$; $* * p<0.01$ compared to control, $\# p<0.01$ compared to high dose

Table 5 Serum biochemistry of rats exposed to $0.5 \% \mathrm{H}_{2} \mathrm{O}_{2}$ mist

\begin{tabular}{|c|c|c|c|c|c|}
\hline Groups & Urea (mg/dL) & Creatinine (mg/dL) & SGPT (ALT) (IU/L) & SGOT (IU/L) & Glucose $(\mathrm{mg} / \mathrm{dL})$ \\
\hline \multicolumn{6}{|l|}{ Male } \\
\hline Control & $43.17 \pm 1.50$ & $0.90 \pm 0.19$ & $83.43 \pm 4.48$ & $215.9 \pm 26 . .89$ & $77.10 \pm 10.27$ \\
\hline Low dose & $38.79 \pm 3.50^{*}$ & $0.89 \pm 0.02$ & $66.55 \pm 33.64$ & $199.0 \pm 4.32$ & $77.20 \pm 11.43$ \\
\hline Medium dose & $38.10 \pm 1.00^{*}$ & $0.62 \pm 0.18$ & $64.40 \pm 18.15$ & $153.5 \pm 41.8^{*}$ & $79.38 \pm 10.81$ \\
\hline High dose & $39.23 \pm 3.96$ & $1.00 \pm 0.14$ & $66.83 \pm 19.28$ & $176.3 \pm 55.57$ & $56.32 \pm 7.40 *$ \\
\hline High dose recovery & $15.32 \pm 2.25 * * \#$ & $1.03 \pm 0.20$ & $71.78 \pm 4.80$ & $128.4 \pm 12.14 * * \#$ & $97.40 \pm 9.00 * * \#$ \\
\hline \multicolumn{6}{|l|}{ Female } \\
\hline Control & $40.63 \pm 1.07$ & $0.94 \pm 0.12$ & $81.38 \pm 18.76$ & $221.4 \pm 27.7$ & $48.38 \pm 3.12$ \\
\hline Low dose & $31.43 \pm 5.20^{*}$ & $1.00 \pm 0.12$ & $82.93 \pm 25.29$ & $170.7 \pm 47.78^{*}$ & $44.60 \pm 19.46$ \\
\hline Medium dose & $37.34 \pm 1.35$ & $1.10 \pm 0.12$ & $69.93 \pm 18.62$ & $173.5 \pm 17.28^{*}$ & $53.10 \pm 18.88^{*}$ \\
\hline High dose & $38.56 \pm 0.33$ & $1.10 \pm 0.12$ & $65.38 \pm 6.29$ & $152.2 \pm 54.39 * *$ & $76.40 \pm 8.63 * *$ \\
\hline High dose recovery & $23.35 \pm 5.68 * * \#$ & $0.91 \pm 0.11$ & $66.05 \pm 7.53$ & $134.2 \pm 5.96^{* *}$ & $82.63 \pm 11.87 * * \#$ \\
\hline
\end{tabular}

Data expressed as mean $\pm \mathrm{SD}, n=4$. Statistical significance was determined using one-way ANOVA followed by Turkey's post hoc test. $* * p<0.01 ; * p$ $<0.05$ compared to control, $\# p<0.01$ compared to high dose 
6). However, slight variation was observed in the creatinine, ALT, total protein, albumin, and ALP level of control animals in comparison with normal reference range. Significant increase was observed in serum cholesterol and urea levels compared to control in hydrogen peroxide mist-exposed male Wistar rats $(p<0.01, p<0.05)$, but all are within the reference range. Similarly, serum glucose levels were also found to be increased in Wistar rats (female) (Table 5). Moreover, serum AST (SGOT) levels were decreased in both male (high dose) and female Wistar rats (low, medium, and high) with respect to control. It was also noted that an increased level of triglycerides occurred in the low and medium dose group of males and high dose group of females. Significant difference was observed in urea, AST, glucose, and cholesterol levels in recovery group in comparison with control and high dose $(p<$ $0.01)$

\section{Gross necropsy}

Necropsy examination of the lungs, cerebrum, cerebellum, liver, spleen, pancreas, kidneys, heart, thymus, adrenal, testes, epididymis, ovaries, uterus, cervix, nasal cavity, pharynx, larynx, and trachea in low, medium, high dose, and high dose recovery group (both male and female) did not reveal any treatment $\left(0.5 \% \mathrm{H}_{2} \mathrm{O}_{2}\right.$ mist)-related gross findings in comparison to control group.

\section{Histopathology}

Histopathological examination of the lungs, cerebrum, cerebellum, liver, spleen, pancreas, kidneys, heart, thymus, adrenal, testes, epididymis, ovaries, uterus, and cervix did not revealed any abnormality in low, medium, high dose, and high dose recovery group in comparison to control group. Similarly, no pathological lesions were evident in nasal cavity, pharynx, larynx, and trachea in low, medium, high dose, and high dose recovery group. Histopathology of control and $0.5 \%$ of $\mathrm{H}_{2} \mathrm{O}_{2}$ mist-exposed tissues of both male and female are shown in Figs. 1a-f, 2a-f, and 3a, b.

\section{Antioxidant assay}

The results depicted in Table 7 revealed that no significant difference was observed in the level-reduced glutathione and glutathione peroxidase with respect to control.

\section{Discussion}

Hydrogen peroxide and its oxidizing nature enabled it to be a part of wide range of applications. Among the various applications, both aqueous and gaseous form of $\mathrm{H}_{2} \mathrm{O}_{2}$ plays a key role in the process of sterilization. Recently, the concept of vapor phase $\mathrm{H}_{2} \mathrm{O}_{2}$ (VPHP) sterilization has been developed as a replacement for EO and formaldehyde sterilants (McEvoy and Rowan 2019). The rationale of the study is to assess the safety of $0.5 \%$ hydrogen peroxide used as a disinfectant compound in the disinfectant gateway developed in concern with current virus pandemic. In the disinfected gateway, the hydrogen peroxide mist is used as a disinfectant to decontaminate the personnel entering a cleaner private space from a public space (Krishnan et al. 2020). Notably, $0.5 \%$ of hydrogen peroxide mist was used in disinfectant gateway by exploiting its application as a disinfectant to reduce the microbial and viral load.

Table 6 Serum biochemistry of rats exposed to $0.5 \% \mathrm{H}_{2} \mathrm{O}_{2}$ mist

\begin{tabular}{|c|c|c|c|c|c|c|}
\hline Groups & Cholesterol (mg/dL) & $\mathrm{TG}(\mathrm{mg} / \mathrm{dL})$ & ALP (IU/L) & Total bilirubin (mg/dL) & Total protein $(\mathrm{g} / \mathrm{dL})$ & Albumin $(\mathrm{g} / \mathrm{dL})$ \\
\hline \multicolumn{7}{|l|}{ Male } \\
\hline Control & $112.3 \pm 8.73$ & $155.8 \pm 3.30$ & $227.0 \pm 103.6$ & $0.25 \pm 0.09$ & $11.07 \pm 4.18$ & $5.30 \pm 1.17$ \\
\hline Low dose & $73.50 \pm 13.00 *$ & $198.8 \pm 26.74$ & $336.0 \pm 90.00 *$ & $0.25 \pm 0.05$ & $9.45 \pm 1.60$ & $5.15 \pm 0.26$ \\
\hline Medium dose & $81.20 \pm 8.75^{*}$ & $185.5 \pm 84.86$ & $336.2 \pm 84.26$ & $0.27 \pm 0.09$ & $10.80 \pm 0.59$ & $5.33 \pm 0.48$ \\
\hline High dose & $89.00 \pm 38.9$ & $154.8 \pm 48.53$ & $364.1 \pm 7.66$ & $0.28 \pm 0.08$ & $10.87 \pm 2.43$ & $5.50 \pm 1.00$ \\
\hline High dose recovery & $61.41 \pm 5.56^{* * \#}$ & $120.3 \pm 21.09$ & $185.9 \pm 68.20^{\#}$ & $0.34 \pm 0.85$ & $9.90 \pm 1.62$ & $5.07 \pm 0.26$ \\
\hline \multicolumn{7}{|l|}{ Female } \\
\hline Control & $80.0 \pm 11.92$ & $100.0 \pm 8.04$ & $181.3 \pm 16.70$ & $0.29 \pm 0.09$ & $10.75 \pm 2.90$ & $5.63 \pm 1.07$ \\
\hline Low dose & $90.3 \pm 22.4$ & $101.5 \pm 27.74$ & $186.3 \pm 18.15$ & $0.34 \pm 0.34$ & $11.90 \pm 2.28$ & $4.98 \pm 0.56$ \\
\hline Medium dose & $84.08 \pm 6.08$ & $150.0 \pm 58.09$ & $190.8 \pm 28.8$ & $0.33 \pm 0.07$ & $10.63 \pm 0.62$ & $5.40 \pm 0.91$ \\
\hline High dose & $78.25 \pm 26.72$ & $214.0 \pm 58.09 * *$ & $203.0 \pm 82.32$ & $0.33 \pm 0.09$ & $11.85 \pm 0.94$ & $5.88 \pm 0.45$ \\
\hline High dose recovery & $56.40 \pm 5.6^{* * \#}$ & $102.3 \pm 18.25^{\#}$ & $110.6 \pm 39.43$ & $0.37 \pm 0.05$ & $10.40 \pm 2.84$ & $5.50 \pm 0.43$ \\
\hline
\end{tabular}

Data are expressed as mean $\pm \mathrm{SD}, n=4$. Statistical significance was determined using one-way ANOVA followed by Tukey's post hoc test. $* * p<0.01$; ${ }^{*} p<0.05$ compared to control, ${ }^{\#} p<0.01$ compared to high dose 
a)

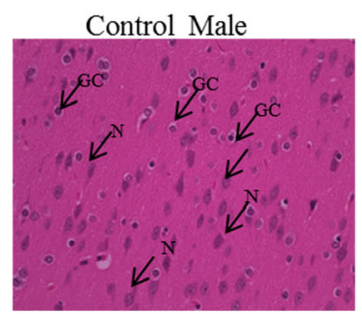

b)

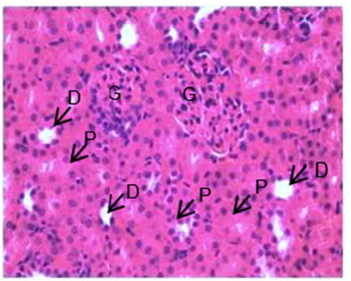

c)

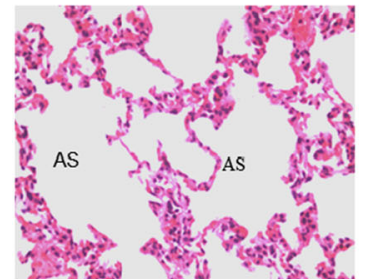

High dose Male
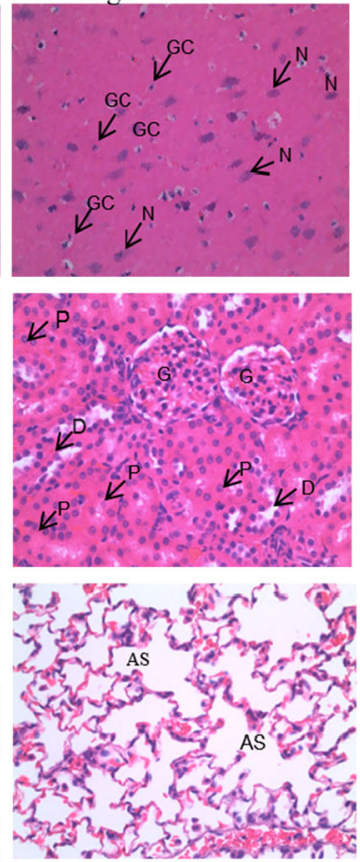

Fig. 1 Histopathology of rats (male) exposed to $0.5 \% \mathrm{H}_{2} \mathrm{O}_{2}$ mist: brain (a): neuron $(\mathrm{N})$, glial cells $(\mathrm{GC})$; kidney $(\mathbf{b})$ : glomeruli $(\mathrm{G})$, proximal convoluted tubule (PCT), distal convoluted tubule (DCT); lung (c):

In the present study, acute skin irritation and repeated-dose inhalation toxicity was carried out to assess safety of $0.5 \%$ of hydrogen peroxide. Skin irritation is considered to be one of the relevant end points of chemicals, and therefore, skin
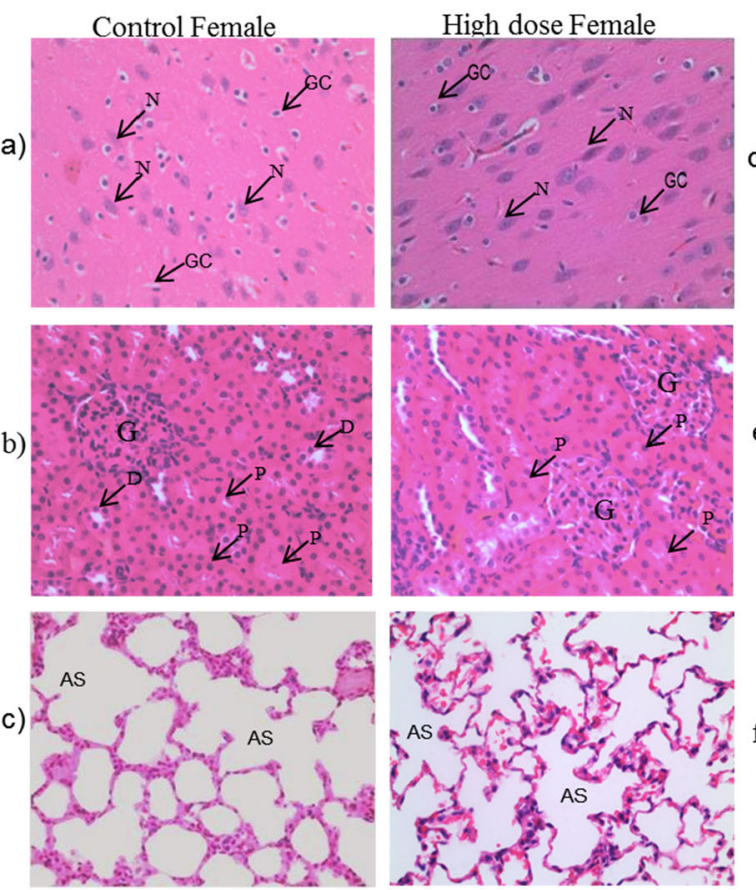

Fig. 2 Histopathology of rats (female) exposed to $0.5 \% \mathrm{H}_{2} \mathrm{O}_{2}$ mist: brain (a): neuron $(\mathrm{N})$, glial cells $(\mathrm{GC})$; kidney $(\mathbf{b})$ : glomeruli $(\mathrm{G})$, proximal convoluted tubule (PCT), distal convoluted tubule (DCT); lung (c):

d)
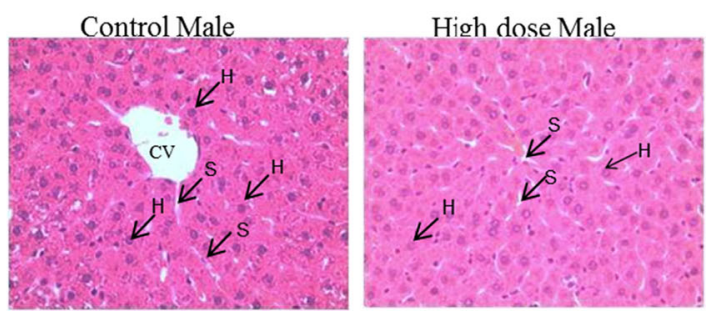

e)
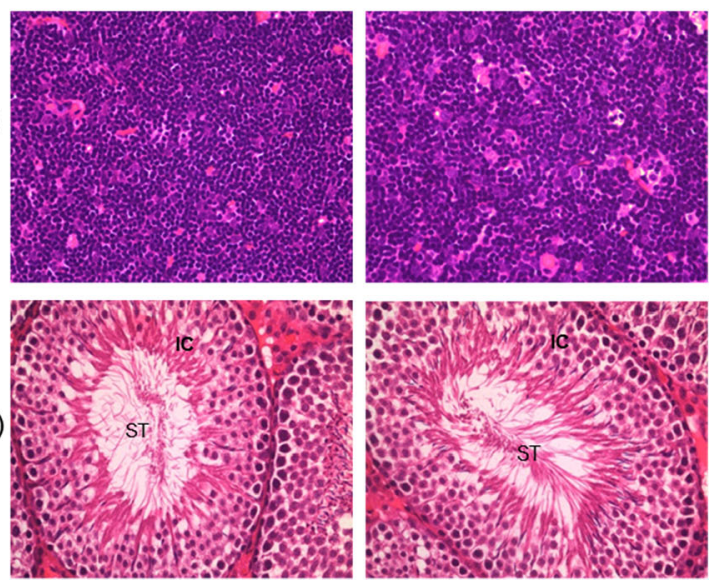

alveolar space (AS); liver (d): central vein (CV), hepatocyte $(\mathrm{H})$, sinusoids (S); testis (f): seminiferous tubule (SF). Magnification $(\times 400)$

irritation test is critical, if dermal contact is intended (Chandra et al. 2015). A study on New Zealand rabbits reported that severity of skin irritation increases within the increase in concentration of hydrogen peroxide solution $(10 \%<35 \%<$
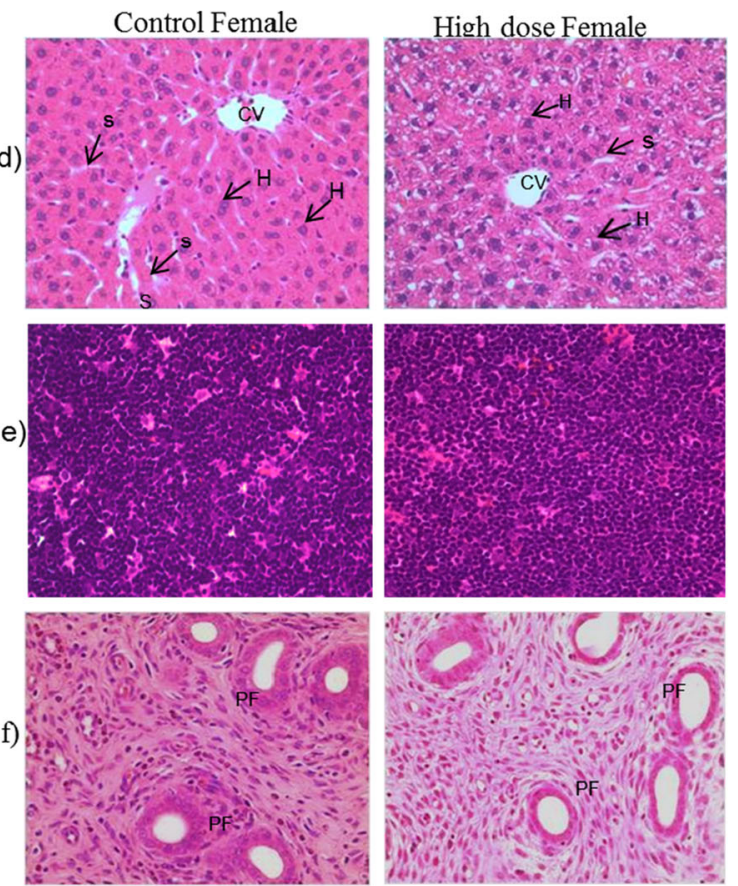

alveolar space (AS); liver (d): central vein $(\mathrm{CV})$, hepatocyte $(\mathrm{H})$, sinusoids (S); ovary (f): primary follicle (PF). Magnification: $\times 400$ 


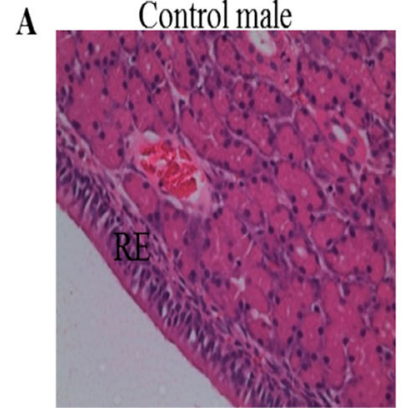

Control female

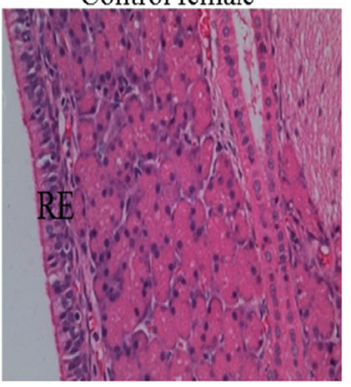

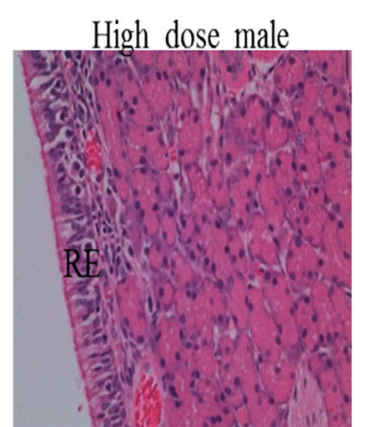

High dose female

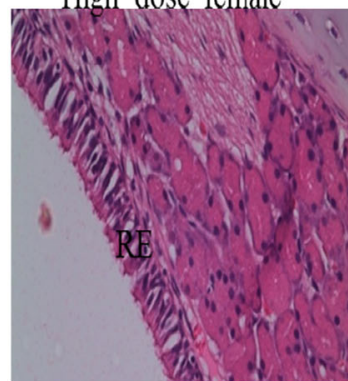

B

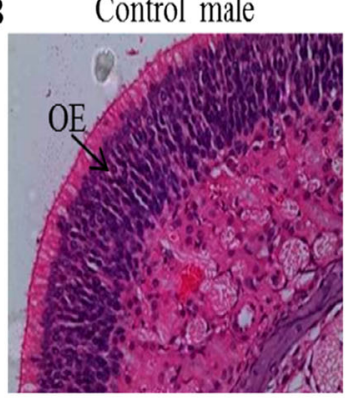

Control female

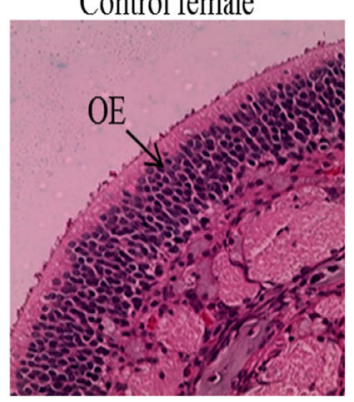

High dose male

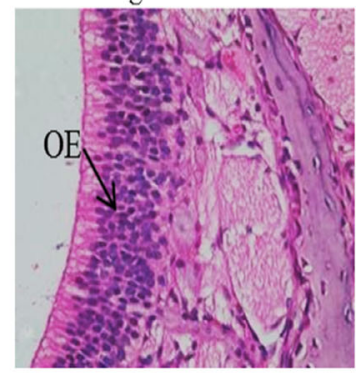

High dose female

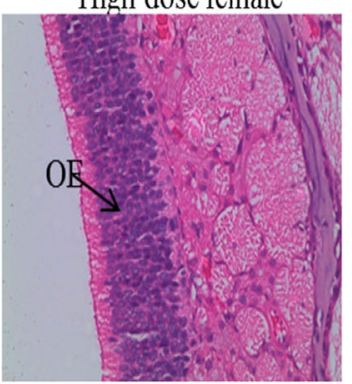

Fig. 3 Histopathology of rats (male and female) exposed to $0.5 \% \mathrm{H}_{2} \mathrm{O}_{2}$ mist: a respiratory epithelial; b olfactory epithelial areas of the nasal cavity. RE, respiratory epithelium; $\mathrm{OE}$, olfactory epithelium. Magnification: $\times 400$

$50 \%$ ). It was also reported that no signs of skin irritation were observed in New Zealand white rabbits administered with 3\% aqueous hydrogen peroxide to intact and abraded skin under occlusion for $24 \mathrm{~h}$ (ECHA 2003). In this study, skin irritation test in rabbits was done to screen any potential hazards of hydrogen peroxide on skin and no evidence of erythema and oedema was observed for $0.5 \%$ of hydrogen peroxide exposure after $24 \mathrm{~h}, 48 \mathrm{~h}$, and $72 \mathrm{~h}$.

Inhalation of chemicals in many industrial workplaces can be a trigger of respiratory tract disorders as well as systemic diseases, depending on the type of inhaled substance and exposure time (Bakand et al. 2005; Camus and Nemery 1998). It has been documented that male Wistar rats were exposed to hydrogen vapor (90\%) in glass chamber for $8 \mathrm{~h}$, sacrificed after 14 days, and showed alveolar emphysema together with severe congestion (ECHA 2003). A subchronic toxicity study on rats exposed to aerosolized hydrogen peroxide (50\% aq.) 5 days per week, $6 \mathrm{~h}$ per day, for 28 days showed clinical signs such as reddened nose, salivation, irregular breathing, respiratory tract irritation, and piloerection, at $14.6 \mathrm{mg} / \mathrm{mL}$ (Oberst et al. 1954). In this present study, repeated-dose exposure study on Wistar rats (male and female) exposed (whole body exposure) to $0.5 \%$ of $\mathrm{H}_{2} \mathrm{O}_{2}$ mist, at a concentration of 11.022 (low dose - 2-min exposure), 22.044 (medium dose4-min exposure), and $55.11 \mathrm{mg} / \mathrm{kg}$ body weight (high dose/ high dose recovery-10-min exposure), daily for 7 days showed no evidence of mortality, clinical toxicity signs, and body weight loss in all study groups compared to control. Gain in body weight was observed in all study groups with respect to control which reflects that $0.5 \%$ of $\mathrm{H}_{2} \mathrm{O}_{2}$ mist may not induce toxicity and all the study group animals found to be healthy.

Hematology and serum biochemical assessments are key tools to assess the physiological and pathological status of the tissue (Corrgan 2011). In this study, the hematological parameters of clinical importance, hemoglobin, white blood cell counts, and platelets were observed to be similar to that of control in both female and male. Wistar rats were exposed to
Table 7 Effect of antioxidant enzymes on exposure of $0.5 \%$ $\mathrm{H}_{2} \mathrm{O}_{2}$ mist to male Wistar rats

\begin{tabular}{lll}
\hline Groups & Reduced GSH (nmol/mg protein) & GPx (units/mg protein) \\
\hline Control & $1.03 \pm 0.02$ & $0.11 \pm 0.60$ \\
Low & $1.04 \pm 0.29$ & $0.11 \pm 0.91$ \\
Medium & $1.10 \pm 0.25$ & $0.12 \pm 0.92$ \\
High & $0.87 \pm 0.03$ & $0.20 \pm 0.17$ \\
High recovery & $0.90 \pm 0.13$ & $0.24 \pm 0.043$ \\
\hline
\end{tabular}

Data are expressed as mean \pm SD. $G p x$, glutathione peroxidase; $G S H$, reduced glutathione Statistical significance was determined using one-way ANOVA followed by Tukey's post hoc test 
$0.5 \%$ of hydrogen peroxide mist. Alternations were observed in red blood cell (RBC) counts with respect to control, in male Wistar rats exposed to hydrogen peroxide mist (low, medium dose). But it may not be consider as a sign of hydrogen peroxide-induced toxicity, since these changes were not observed in high exposure level. However, hematological indices $\mathrm{HCT}, \mathrm{MCV}$, and MCHC were significantly decreased in male Wistar rats at low- and medium-dose exposure of hydrogen peroxide mist and at high dose in females. This variation may be due to age, reproductive status, housing, starvation, environmental factors, stress, and transportation (Waziri et al. 2010).

The pathological of condition of internal organs after exposure to hydrogen peroxide mist was revealed by serum biochemistry. Variation observed in the creatinine, ALT, total protein, albumin, and ALP levels of control animals in comparison with the normal reference range was suggested by CPCSEA (CPCSEA 2003). A significant decrease in serum AST levels was observed in female Wistar rats exposed to hydrogen peroxide (low, high, medium, and recovery groups) with respect to control, whereas in male Wistar rats, significant difference was observed at medium and recovery groups with respect to control but all are within the reference range. It was also found that alkaline phosphatase levels (ALP) increased in male Wistar rats at low dose but no such increase was observed at high dose with respect to control. It has been reported that breed, sex, age, and reproductive status; time of feeding, diurnal variations, nutritional state, and management; and geographical/climatic factors influence serum parameters (Corrgan 2011). It was also documented that many of the hematological and biochemical parameters are in association with developmental changes (Lillie et al. 1996), so the alternations in serum AST and ALP levels may be due to such variation than the effect of hydrogen peroxide. Significant difference was observed in serum urea and cholesterol levels in male Wistar rats exposed to hydrogen peroxide, in comparison with control but all are within the reference range. In recovery groups, most of the test parameters were found to be comparable with that of control. Nonetheless, significant decreases in urea levels were observed in male Wistar rat. Further, negligible differences observed with regard to hematological and biochemical parameters may not be considered as toxicological or biological significance as the results were comparable to that of control, and most of the changes were not related to the exposure.

In our study, histopathological results revealed no abnormalities or pathological alternations in the tissues examined. All the tissues, lungs, cerebrum, cerebellum, liver, spleen, pancreas, kidneys, heart, thymus, adrenal, testes, epididymis, ovaries, uterus, cervix, nasal cavity, pharynx, larynx, and trachea, examined after $0.5 \% \mathrm{H}_{2} \mathrm{O}_{2}$ mist exposure (low, medium, high dose, and high dose recovery group) remain intact, similar to that of control. Studies have been documented on the morphological complexity and the importance of upper respiratory tract in inhalation toxicity studies (Herbert et al. 2018). It was also reported that inhalation of chemicals may affect the pulmonary epithelium of the respiratory tract (Gorguner and Akgun 2010). Toxicants or irritant chemicals induce frequent lesions such as necrosis, erosion, and ulceration of the respiratory epithelium. We observed, no hydrogen peroxideinduced alternations, even though few infrequent lesions observed in control rats may be due to microbial infections. Overall histopathological analysis revealed no signs of toxicity in all study groups.

Oxidative stress, an imbalance between reactive oxygen species (ROS) and the antioxidant defence mechanism of cells or tissues, leads to rapid glutathione depletion, decreasing antioxidant enzyme, lipid peroxidation, and DNA damage (Valko et al. 2016). Antioxidant enzyme system play key role in defence against free radical-induced oxidative damage. It has been reported that hydrogen peroxide $(100 \mathrm{mg} / \mathrm{kg}$ body weight) induced alternations in antioxidant enzyme activity in mice (Yalçın et al. 2020). In normal conditions, the glutathione/glutathione peroxidase system maintains the hydrogen peroxide levels by breaking down to oxygen and water (Reid et al. 2011). In this study, antioxidant levels (reduced glutathione and GPx) after exposure to $0.5 \%$ hydrogen peroxide mist were assessed; no significant difference was observed in reduced glutathione and GPx activity in all study group animals exposed to $0.5 \%$ of $\mathrm{H}_{2} \mathrm{O}_{2}$ mist, at a concentration of 11.022 (low dose-2-min exposure), 22.044 (medium dose4-min exposure), and $55.11 \mathrm{mg} / \mathrm{kg}$ body weight (high dose/ high dose recovery-10-min exposure), daily for 7 days with respect to control. These results indicate that $0.5 \%$ of $\mathrm{H}_{2} \mathrm{O}_{2}$ mist may not induce any toxicity.

The result of the present study concludes that there was no skin irritation potential such as oedema or erythema or necrosis on exposure to $0.5 \% \mathrm{H}_{2} \mathrm{O}_{2}$ in rabbits. Similarly, the inhalation toxicity of $0.5 \%$ of $\mathrm{H}_{2} \mathrm{O}_{2}$ mist, intended to be used for disinfection gateway for COVID-19, was well tolerated by Wistar rats (both male and female). Further, at the laboratory condition stimulated, the NOEL was found to be $55.11 \mathrm{mg} / \mathrm{kg}$ body weight. Hence, the present study concluded that $0.5 \%$ $\mathrm{H}_{2} \mathrm{O}_{2}$ or its mist used in the disinfection gateway for COVID19 failed to induce any skin irritation in rabbits and inhalation toxicity in rats.

Acknowledgements The authors express their thanks to the Director and Head, Biomedical Technology Wing, Sree Chitra Tirunal Institute for Medical Sciences and Technology (Govt. of India), Trivandrum, Kerala, India, for their support and providing the infrastructure to carry out this work.

Author contribution Mohanan, corresponding author: conception, design of the study, analysis, and interpretation of data, drafting, critical revision, and final approval; Sangeetha: acquisition of data, drafting, 
and interpretation of data; Sabareeswaran, Vandana, and Varsha: acquisition of data and drafting; Muraleedharan and Jithin: acquisition of data and drafting.

Data availability The authors declared that the research data referred correctly cited in the manuscript's reference section. All the raw data are available with the parent institute.

\section{Declarations}

Ethics approval Experiments were conducted after obtaining approval from the Institutional Animal Ethics Committee. The animal care and handling was done according to the CPCSEA guidelines for animal experimentation (Institutional Animal Ethics Committee approval no: SCT/ IAEC-320/FEBRUARY/2019/101 (skin irritation) and SCT/IAEC-345/ May/2020/105 (inhalational toxicity)).

Consent to participate Since all experiments are in animals, the consent part from the subject is not applicable in the study.

Consent to publish All the authors agreed to submit the manuscript in the journal. The same has been approved by the parent institute.

Competing Interests The authors declare no competing interests.

\section{References}

Agency for Toxic Substances and Disease Registry (ATSDR) (2002) Managing hazardous materials incidents. volume III - medical managementguidelines for acute Chemical exposures: Hydrogen Peroxide. Atlanta, GA: U.S. Department of Health and Human Services, Public Health Service. https://wwwn.cdc.gov/TSP/ ToxFAQs/ToxFAQsDetails.aspx?faqid=305\&toxid=55, https:/ www.atsdr.cdc.gov/toxfaqs/tfacts174.pdf

Bakand S, Winder C, Khalil C, Hayes A (2005) Toxicity assessment of industrial chemicals and airborne contaminants: transition from in vivo to in vitro test methods: a review. Inhal Toxicol 17:775787. https://doi.org/10.1080/08958370500225240

Camus PH, Nemery B (1998) A novel cause for bronchiolitis obliterans organizing pneumonia: exposure to paint aerosols in textile workshops. Eur Respir J 11:259-262. https://doi.org/10.1183/09031936. 98.11020259

Chandra SA, Stokes AH, Hailey R, Merrill CL, Melich DH, DeSmet K, Furst SM, Peterson RA, Mellon-Kusibab K, Adler RR (2015) Dermal toxicity studies: factors impacting study interpretation and outcome. Toxicol Pathol 43:474-481. https://doi.org/10.1177/ 0192623314548765

Corrigan R (2011) Fundamentals of Veterinary Clinical Pathology, 2nd edition. Can Vet J 52(2):161. PMCID: PMC3022453

Ernstgard L, Sjögren B, Johanson G (2012) Acute effects of exposure to vapors of hydrogen peroxide in humans. Toxicol Lett 212:222-227. https://doi.org/10.1016/j.toxlet.2012.05.025

European Chemical Industry Council (CEFIC) (2002) Hydrogen peroxide: 28-day inhalation study. CTL study No. MR0211, Degussa Report No. 2002-0082-DKT, Cefic Peroxygens Sector Group, Hydrogen Peroxide Sub Group, Brussels,Belgium. https:// specialty-chemicals.eu/wp-content/uploads/2017/07/4 HydrogenPeroxide-Classification-and-Labelling-2015.pdf

European Chemicals Agency (ECHA) (2003) Hydrogen peroxide, EC number 231-765-0/CAS number 7722-84-1. https://echa.europa. eu/documents/10162/590965ca-33e7-43a0-a109-3a9148870d07, https://echa.europa.eu/bg/registration-dossier/-/registereddossier/ $15701 / 7 / 1$

Experiments on Animals (203) Committee for the Purpose of Control and Supervision on Experiments on Animals (CPCSEA) guidelines for laboratory animal facility. Indian J Pharmacol 35:257-74

Gorguner M, Akgun M (2010) Acute inhalation injury. Eurasian J Med 42(1):28-35. https://doi.org/10.5152/eajm.2010.09

Hartwig A, Arand M (2019) MAK Commission. Hydrogen peroxide. The MAK Collection for Occupational Health and Safety 4(4): 2108-2113. https://doi.org/10.1002/3527600418.mb772284e6619

Herbert RA, Janardhan KS, Pandiri AR, Cesta MF, Miller RA (2018) Nose, larynx, and trachea. In Boorman's pathology of the Rat. pp. 391-435. https://doi.org/10.1016/B978-0-12-391448-4.00022-8

International Organization for Standardization (2010) Biological evaluation of medical devices - part 10: tests for irritation and skin sensitization (ISO 10993-10: 2010). https://www.iso.org/standard/40884. html

Krishnan J, Subhash NN, Muraleedharan CV, Mohanan PV, Neethu S, Rethnagireeshwar R (2020) Chitra disinfection gateway for the management of COVID 19 in public entry places. Trans Indian Natl Acad 4:1-6. https://doi.org/10.1007/s41403-020-00144-4

Lerouge S, Simmons A (2012) 5 - Non-traditional sterilization techniques for biomaterials and medical devices, Sterilisation of Biomaterials and Medical Devices, Woodhead Publishing, pp. 97-116. http:// www.gbv.de/dms/tib-ub-hannover/654193851.pdf

Lillie LE, Temple NJ, Florence LZ (1996) Reference values for young normal Sprague-Dawley rats: weight gain, haematology and clinical chemistry. Hum Exp Toxicol (8):612-6. https://doi.org/10.1177/ 096032719601500802

Linley E, Denyer SP, McDonnell G, Simons C, Maillard JY (2012) Use of hydrogen peroxide as a biocide: new consideration of its mechanisms of biocidal action. J Antimicrob Chemother 67(7):15891596. https://doi.org/10.1093/jac/dks129

Lowry OH, Rosebrough NJ, Farr AL, Randall RJ (1951) Protein measurement with the folin phenol reagent. J Biol Chem 193:265-227 https://www.scienceopen.com/document?id=14925728-aac2-4346b306-ae7a5d8e0706

McDonnell G (2009) The use of hydrogen peroxide for disinfection and sterilization applications. Patais Chemistry of Functional Groups 15: 1-3. https://doi.org/10.1002/9780470682531.pat0885

McEvoy B, Rowan NJ (2019) Terminal sterilization of medical devices using vaporized hydrogen peroxide: a review of current methods and emerging opportunities. J Appl Microbiol 27:1403-1420. https://doi.org/10.1111/jam.14412

Moron MS, Depierre JW, Mannervik B (1979) Levels of glutathione, glutathione reductase and glutathione S-transferase activities in rat lung and liver. Biochim Biophys Acta 582:67-78. https://doi.org/ 10.1016/0304-4165(79)90289-7

Munn S, Allanou R, Aschberger K, Berthault F, De Bruijn J, Musset C, O`Connor S, Pakalin S, Pellegrini G, Scheer S, Vegro S. European Union RiskAssessment Report. Hydrogen Peroxide. CAS No. 7722-84-1. EINECS No. 231-765-0. EUR 20844 EN. 2003. JRC26024. https://publications.jrc.ec.europa.eu/repository/handle/ JRC26024

Murdoch LE, Bailey L, Banham E, Watson F, Adams NM, Chewins J (2016) Evaluating different concentrations of hydrogen peroxide in an automated room disinfection system. Lett Appl Microbiol 63(3): 178-182. https://doi.org/10.1111/lam.12607

OECD (2018) Test No. 412: subacute inhalation toxicity: 28-day study, OECD Guidelines for the Testing of Chemicals, Section 4, OECD Publishing, Paris. https://www.oecd.org/env/ehs/testing/test-no412-subacute-inhalation-toxicity-28-day-study-9789264070783-en. htm

Oberst FW,Comstock CC,Hackley BB (1954). Inhalation toxicity of ninety percent hydrogen peroxide vapor; acute, subacute, and 
chronic exposures of laboratory animals. AMA Arch Ind Health. 1954 Oct;10(4):319-27.

Reid CJ, Alcock M, Penn D (2011) Hydrogen peroxide-a party trick from the past? Anaesth Intensive Care 3(6):1004-1008. https://doi.org/ 10.1177/0310057X1103900604

Rotruck JT, Pope AL, Ganther HE, Swanson AB, Hafeman DG, Hoekstra WG (1973) Selenium: biochemical role as a component of glutathione peroxidase. Science 179:588-590. https://doi.org/10. 1126/science.179.4073.588

Rutala WA, Weber DJ (2015) Disinfection, Sterilization, and Control of Hospital Waste. Mandell, Douglas, and Bennett's Principles and Practice of Infectious Diseases. https://doi.org/10.1016/B978-14557-4801-3.00301-5

Stockham SL, Scott MA (2013) Fundamentals of veterinary clinical pathology. John Wiley \& Sons. https://www.worldcat.org/title/ fundamentals-of-veterinary-clinical-pathology/oclc/165048825.

Suenaka T, Akaska S, Hirata M (1984) A survey of occupational exposure to hydrogen peroxide- $-\mathrm{H} 2 \mathrm{O} 2$ exposure level and its effects on lipid peroxide and its related enzyme activities. In: Proceedings of Osaka Prefecture Institute of Public Health, Edition of Industrial Health. 22:9-13
Tuladhar E, Terpstra P, Koopmans M, Duizer E (2012) Virucidal efficacy of hydrogen peroxide vapour disinfection. J Host Infect 80:110 115. https://doi.org/10.1016/j.jhin.2011.10.012

Valko M, Jomova K, Rhodes CJ, Kuča K, Musílek K (2016) Redox-and non-redox-metal-induced formation of free radicals and their role in human disease. Arch Toxicol 90:1-37. https://doi.org/10.1007/ s00204-015-1579-5

Watt BE, Proud foot AT, Vale JA (2004) Hydrogen peroxide poisoning. Toxicol Rev 23:51-57. https://doi.org/10.2165/00139709200423010-00006

Waziri MA, Ribadu AY, Sivachelvan N (2010) Changes in the serum proteins, haematological and some serum biochemical profiles in the gestation period in the Sahel goats. Vet Arhi 80:215-224 https:// hrcak.srce.hr/56497

Yalçın E, Çavuşoğlu K, Acar A, Yapar K (2020) In vivo protective effects of Ginkgo biloba L. evaluation. Cytogenetic and biochemical evaluation. Environ Sci Pollut Res 27(3):3156-3164. https://doi. org/10.1007/s11356-019-07156-w

Publisher's note Springer Nature remains neutral with regard to jurisdictional claims in published maps and institutional affiliations. 